\title{
jurnal_febry_1_1.docx by
}

Submission date: 03-Jan-2022 09:53AM (UTC+0700)

Submission ID: 1736981565

File name: jurnal_febry_1_1.docx (42.91K)

Word count: 4070

Character count: 25815 


\title{
KOMPONEN PERANGKAT KERAS KOMPUTER \\ Device Hardware Components Computer
}

Febry Pratama : (0702212202)

Prodi : Sistem Informasi-VI

Fakultas Sains dan Teknologi UIN SU

Email : febryprima111@gmail.com

No HP : 082370750141

\begin{abstract}
ABSTRAK
Peralatan adalah gadget yang harus terlihat dan dihubungi langsung oleh orangorang, peralatan PC adalah setiap bagian sebenarnya dari PC, terpisah dari informasi yang ada atau berhubungan dengannya, sedangkan pemrograman adalah gadget yang harus terlihat tetapi tidak dihubungi langsung oleh orang. . individu. Membaca dengan teliti, pemrograman ${ }_{26} \mathrm{ng}$ memberikan pedoman untuk peralatan untuk melakukan usaha. Peralatan adalah 19 lah satu bagian dari PC yang sifatnya harus dapat dilihat dan dihubungi, baik secara langsung maupun tidak langsung, untuk membantu interaksi komputerisasi.

Dalam aplikasi peralatan atau tambahan dengan istilah Perangkat Keras [Hardware]. Setiap PC direncanakan dengan spesifikasi gadgetnya sendiri. Setiap PC memiliki kecepatan dan manfaatnya sendiri. Sebenarnya, PC terdiri dari beberapa bagian yang membentuk kerangka kerja. Kerangka adalah atau juga membentuk bagian-bagian yang bekerja sama untuk membentuk satu kesatuan. Setiap peralatan memiliki kapasitasnya masing-masing. Dengan cara ini, setiap peralatan tidak bisa dibiarkan sendiri, namun banyak bagian ini saling mendukung. Semua peralatan mengharapkan pemrograman untuk hidup dan bekerja.

Peralatan adalah gadget yang harus terlihat dan dihubungi langsung oleh orangorang. Perangkat PC adalah setiap bagian dari PC yang sebenarnya, dikenali dari informasi yang ada di dalamnya atau yang bekerja di dalamnya, sedangkan pemrograman adalah gadget yang harus terlihat tetapi tidak dapat dihubungi langsung oleh orang. , (pemrograman) yang memberikan arahan kepada peralatan untuk menyelesaikan tanggung jawab. Peralatan adalah salah satu bagian dari PC yang sifatnya harus terlihat dan dihubungi secara langsung atau
\end{abstract}


dalam struktur yang jelas yang berfungsi untuk membantu interaksi komputerisasi.

Catchphrases: Perangkat Keras, Unit (Perangkat Input), Gadget Proses (Processing Unit), Gadget Keluaran (Unit Output) Sistem Perangkat Keras (Input Device System)

\footnotetext{
ABSTRACT

Hardware is a device that can be seen and touched directly by humans, computer hardware is any physical part of the computer, separate from the data that resides or works on it, while software is a device that can be seen but not touched directly by humans. people.

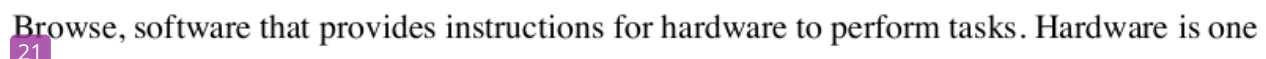
of the components of a computer, whose nature can be seen and touched, either directly or indirectly, to help the computerization process.

In hardware applications or also with the term Hardware [Hardware]. Each computer is designed with its own device specifications. Each computer has its own speed and advantages. Physically, a computer consists of several components that constitute a system. The system is or also forms components that work together to form a single unit. Each piece of hardware has its own function. Therefore, each hardware cannot stand alone, but all these components support each other. All hardware requires software to turn on and function.

Hardware is a device that can be seen and touched physically directly by humans, Computer hardware is all physical parts computer, as distinguished by the data contained in it or operating on it while software is a device that can be seen but cannot be seen touched directly by humans, the software that provides instructions for hardware to complete the task. Hardware (hardware) is one of the components of a computer whose properties can be seen and directly touched or in tangible form that serves to support the process computerized.

Keywords: Hardware, Unit Input (Input Device), Process device (Processing Unit), Output device (Unit Output) Hardware System Input (Input Device System)
} 


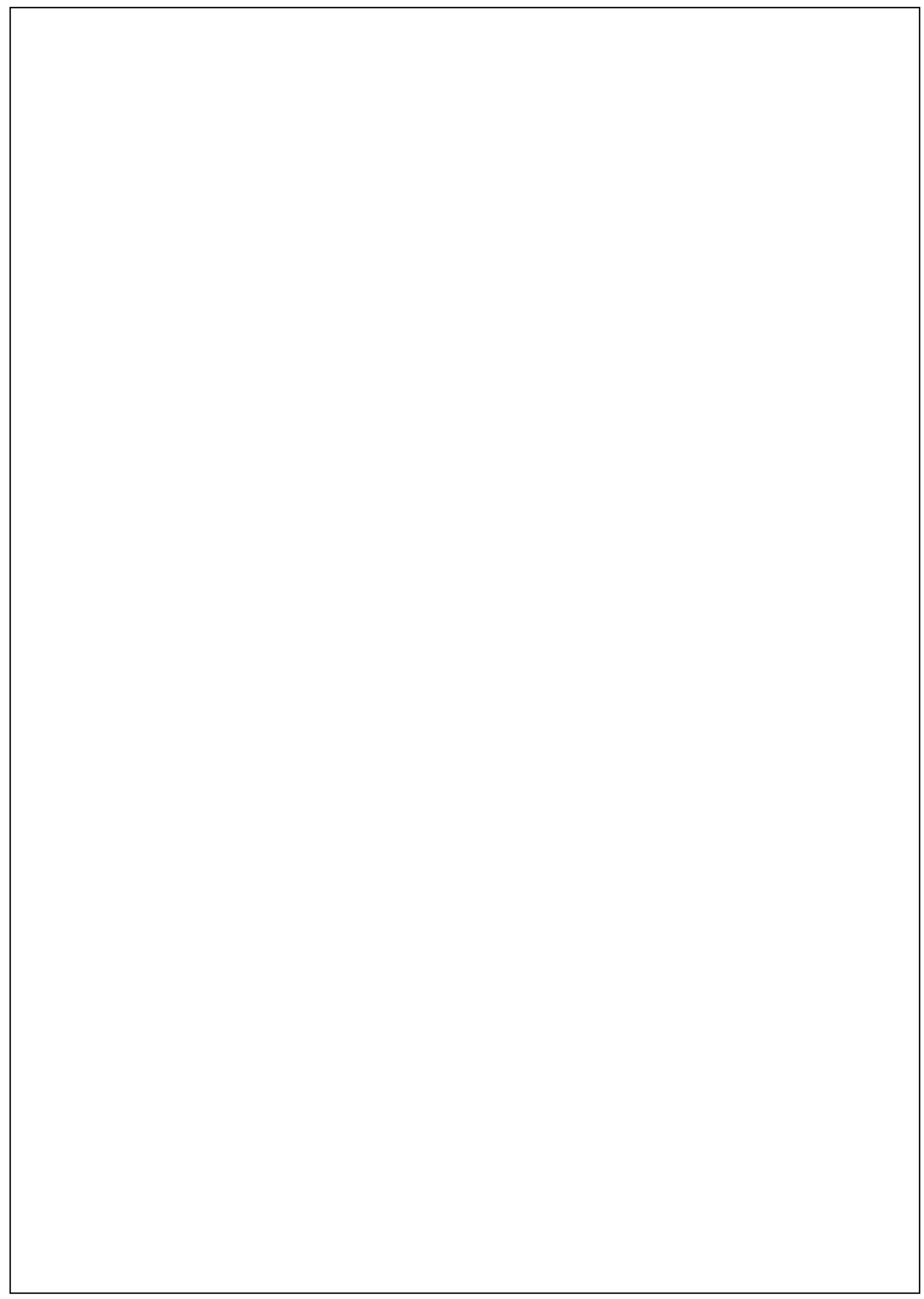




\section{PENDAHULUAN}

Saat ini kita hidup dalam kesempatan saat ini. Dimana dunia semakin halus dan maju, khususnya dalam bidang inovasi. Inovasi seperti yang ditunjukkan oleh wikipedia adalah seluruh sarana untuk memberikan produk yang diharapkan untuk ketahanan dan pelipur lara keberadaan manusia. Jadi inovasi berhubungan erat dengan manusia. Mungkin inovasi paling trend setting adalah PC. Pada awalnya, kapasitas PC sama sekali berbeda dengan ka ${ }_{2}$ sitas $\mathrm{PC}$ saat ini. Sebelumnya, PC digunakan sebagai alat olahraga. Sesuai dengan bahasa latin computare yang artinya menghitung. Namun, PC mengalami pergantian peristiwa yang sangat cepat, saat ini PC tidak digunakan secara umum sebagai alat pemeriksa tetapi PC dapat digunakan sebagai perangkat elektronik.

untuk berurusan dengan kata-kata dan informasi. Bagaimanapun, kapasitas PC tidak hanya itu, PC telah berubah menjadi inovasi yang kompleks dan dapat dikatakan sebagai instrumen yang fleksibel. Di dalam PC terdapat dua gadget penting untuk membantu proses kerja PC. Gadget ini adalah peralatan dan pemrograman. Peralatan adalah gadget yang harus terlihat dan dihubungi langsung oleh orang-orang, peralatan PC adalah setiap bagian dari PC yang sebenarny 16 dikenali dari informasi yang ada di dalamnya atau yang bekerja di dalamnya, sedangkan pemrograman adalah gadget yang harus terlihat. namun tidak bisa dihubungi langsung oleh orang. pemrograman yang memberikan arahan kepada peralatan untuk menyelesaikan tanggung jawab.

Peralatan yang disebut peralatan adalah semua bagian dari PC. Perangkat adalah perangkat yang harus dapat dilihat dan dirasakan secara langsung sebagai bentuk hasil dari setiap proses kerja sistem dari PC yang sebenarnya. Padahal, untuk membantu atau menjalankan sistem kerja, gadget sebenarnya membutuhkan pemrograman atau program semacam itu agar berfungsi dengan baik. Peralatan atau perlengkapan dapat diurutkan menjadi lima bagian, yaitu gadget masukan (input/input gadgets), gadget proses (process gadgets), gadget hasil (yield gadgets), periferal (gadget tambahan/embel-embel) dan memori luar (batu informasi). ). ).

Untuk menangani kata-kata 2 n informasi. Namun, kapasitas PC tidak hanya itu, PC telah menjadi inovasi yang disempurnakan dan dapat dikatakan sebagai perangkat yang mudah beradaptasi. Di dalam PC terdapat dua gadget penting untuk membantu proses kerja PC. Gadget ini adalah peralatan dan pemrograman. Peralatan adalah gadget yang harus terlihat dan dihubungi langsung oleh orang-orang, peralatan PC adalah setiap bagian sebenarnya dari $\mathrm{PC}$, terpisah dari informasi yang ada atau terkelupas di dalamnya, sedangkan pemrograman adalah gadget yang harus terlihat namun tidak dapat dihubungi langsung oleh orang lain. rakyat. individu. Individu, pemrograman yang memberikan panduan kepada peralatan untuk melakukan pekerjaan Perangkat keras adalah salah satu bagian PC, yang harus terlihat dan dihubungi, baik secara langsung atau secara tersirat, untuk membantu siklus komputerisasi.

Peralatan PC yang dikenal dapat diatur menjadi tiga kelompok:

- perangkat masukan

- perangkat pemrosesan 
- perangkat keluaran

Gadget input adalah perangkat keras yang biasanya kita gunakan untuk memasukkan informasi ke dalam PC, seperti konsol, mouse, dan pemindai. Handling gadget adalah peralatan yang biasanya mengolah informasi menjadi data, yang pasti berubah menjadi "pikiran" mesin PC dalam menyelesaikan perintah yang diberikan. Alat pengendali ini biasa disebut CPU atau juga prosesor.

Peralatan dapat bekerja tergantung pada permintaan yang telah ditentukan sebelumnya

ada di dalamnya, pasti disebut set panduan.

Saat ini kita hidup dalam kesempatan saat ini. Dimana dunia semakin halus dan maju, khususnya dalam bidang inovasi. Inovasi menurut wikipedia adalah perangkat umum untuk memberikan produk yang diharapkan untuk ketahanan dan pelipur lara keberadaan manusia. Jadi inovasi

berhubungan erat dengan orang-orang.

Sangat mungkin inovasi yang paling trend setting adalah PC. Pada

Pertama, kapasitas PC sama sekali berbeda dengan kapasitas $\mathrm{P}_{2}$ saat ini.

Sebelumnya, PC digunakan sebagai alat olahraga. Sesuai dengan bahasa latin computare yang artinya menghitung. Bagaimanapun, PC telah berkembang pesat, pada saat ini PC tidak digunakan secara umum

sebagai alat olahraga tetapi PC dapat digunakan sebagai alat elektronik untuk menangani kata-kata dan informasi. Bagaimanapun, kapasitas PC tidak hanya itu, PC telah berubah menjadi inovasi modern dan dapat dianggap sebagai perangkat lintas batas. Di PC ada dua gadget

vital untuk membantu proses kerja PC. Gadget ini adalah peralatan dan pemrograman. Peralatan adalah sebuah gadget yang harus dapat dilihat dan dihubungi langsung oleh orang-orang, peralatan PC adalah setiap bagian dari PC yang sebenarnya, yang dikenali dari informasi di dalamnya atau bekerja di dalamnya sedangkan pemrograman adalah gadget yang harus terlihat namun dapat tidak bisa dihubungi langsung oleh orangorang, program yang memberikan pedoman untuk membuat peralatan untuk menyelesaikan suatu pekerjaan.

Peralatan PC adalah setiap bagian sebenarnya dari sebuah PC, 22 n dikenali dari informasi yang hidup di dalamnya atau yang bekerja di dalamnya, dan dikenali dari pemrograman yang memberikan panduan kepada peralatan dalam menyelesaikan tugasnya.

PC sesuai spesialis di bidangnya:

\section{1). Ali Zaki}

Seperti yang ditunjukkan oleh Ali Zaki, pemikiran peralatan adalah bagian sebenarnya dari PC, mengingat sirkuit canggih untuk perangkat keras PC.

\section{2). Raya Fahreza}

Sesuai Raya Fahreza, peralatan sangat penting untuk PC yang berfungsi sesuai arahan pemrograman.

\section{3). R. Wilman dan Riyan}

Menurut R. Wilman dan Riyan, yang dimaksud dengan peralatan adalah perkembangan gadget elektronik yang 
dipadatkan pada telepon seluler yang 17pasitasnya terkait dengan gadget menjadi satu bagian yang tidak terpisahkan.

4). hujan

printer.Kapasitas perangkat keras untuk 12endapatkan informasi/data, memutar dan menampilkan data mentah menjadi data baru yang bermanfaat.

\section{5). James O'Brien}

Menurut James O'Brien, peralatan adalah semua peralatan aktual yang digunakan dalam penanganan data, termasuk CPU, RAM, layar, mouse, konsol, printer, pemindai, dan lainnya. P7ralatan adalah media korespondensi yang menghubungkan beberapa organisasi dan siklus paket informasi sehingga transmisi informasi lebih menarik.

\section{6). Joko Untoro}

Menurut Joko Untoro, yang dimaksud dengan peralatan adalah gadget yang sebenarnya seperti PC dan segala perangkat pendukungnya.

\section{Fungsi Komponen Hardware}

\section{Unit Masukan (Input Device)}

Unit ini berfungsi sebagai mekanisme untuk memasukkan informasi dari luar ke dalam memori dan prosesor yang akan ditangani untuk membuat data yang diperlukan. Gadget input atau unit info yang umumnya digunakan (PC) adalah konsol dan mouse. Konsol dan mouse adalah unit yang menghubungkan (klien) dengan PC. Juga ada joystick, yang biasanya digunakan untuk mainmain atau bermain game dengan PC. Kemudian, pada sశ్2t itu, pemindai, menerima gambar sebagai gambar terkomputerisasi yang nantinya dapat dikendalikan. Contact board, dengan memanfaatkan sedikit (2) ri klien dapat memainkan proses akses dokumen. Micophone, untuk merekam suara ke dalam PC. (Wordpress.com.id, 2012) Informasi yang masuk ke dalam framework PC dapat berupa sinyal info dan sinyal input pendukung sebagai input sebagai informasi yang masuk ke dalam framework PC, sedangkan input pemeliharaan berupa proyek yang digunakan untuk menangani informasi yang masuk. . Untuk memasukkan informasi juga dapat digunakan untuk masuk ke program. Berdasarkan kecen(2 rungannya, perangkat keras input dapat dibagi menjadi dua, lebih spesifiknya: peralatan informasi langsung, yaitu input yang dimasukkan langsung ditangani oleh prosesor. Misalnya: Keyboard, Mouse, Layar sentuh, Pena ringan, Tablet ilustrasi digitizer, Pemindai. Perangkat informasi 24 yang berputar, kontribusi melalui media tertentu sebelum suatu informasi ditangani oleh gadget yang menangani. Contoh : Punched card, disket, hard circle. Unit info atau gadget informasi ini 
terdiri dari beberapa macam gadget, yaitu:

1) Papan ketik

Konsol adalah unit informasi utama dalam penanganan informasi dengan PC. Konsol dapat bekerja

memasukkan huruf, angka, karakter luar biasa hanya sebagai modus bagi klien (klien) untuk melakukan perintah penting lainnya, seperti menyimpan dokumen dan membuka catatan. Pembentukan konsol PC berawal dari model mesin tik yang dibuat dan dilindungi oleh Christopher Latham pada tahun 1868, dan pada tahun 1887 dibuat dan dipromosikan oleh organisasi Remington Keyboard yang didapat dari model mesin tik yang dirancang dan dilisensikan oleh Chistoper Latham pada tahun 1868.

\section{Ada bebrapa jenis Keyboard:}

\section{$\square$ Papan ketik QWERTY}

Tata letak keyboard QWERTY ditemukan oleh Scholes, Ghildden dan Soule pada tahun 1878, dan kemudian menjadi mesin tik fandar komersial pada tahun 1905. Contoh paling jelas dari inefisiensi tata letak QWERTY adalah mengetik huruf a, yang cukup sering digunakan, tetapi harus dilakukan oleh jari kelingking. yang paling lemah.

\section{$\square$ Papan Ketik Dvorak}

Keyboard DVORAK (1932), dimana susunan hurufnya diatur sedemikian rupa sehingga tangan kanan dibebani lebih banyak pekerjaan daripada tangan kiri. Sejumlah percobaan menunjukkan bahwa tata letak Dvarok 10-15 persen lebih efisien daripada tata letak QWERTY.

\section{Papan Ketik KLOCKENBERG}

Keyboard ini dibuat dengan tujuan untuk m3nyempurnakan jenis keyboard (kiri dan kanan). Bagian kiri dan kanan keyboard dipisahkan oleh sudut 15 derajat dan dimiringkan ke bawah. Selain itu, keyboard KLOCKENBERG memiliki tombol yang dibuat lebih dekat (tipis) dengan meja kerja sehingga terasa lebih nyaman. Tata letak ini, selain untuk mengurangi beban otot pada jari dan pergelangan tangan, juga dirancang untuk mengurangi beban otot pada tangan dan bahu.

5) tikus

Mouse adalah perangkat keras input yang digunakan untuk menggerakkan pointer atau kursor. Selain itu, ini bisa menjadi perintah yang praktis dan lebih cepat daripada keyboard. Mouse terdiri dari beberapa port yaitu serial mouse, ps/2 mouse, usb dan wireless.

Jenis tikus:

Mouse manual/tikus mekanis Mouse jenis ini bekerja dengan sistem bola karet yang terletak di pangkal mouse dan saat digunakan bola akan bergesekan dengan media alas, sehingga selanjutnya 
dapat menggerakkan sensor $\mathrm{x}$ dan y.

b) Serial Mouse, Biasa digunakan pada Pentium 1 dan 2. Mouse dengan konektor serial (RS 232C).

c) Mouse konektor PS/2 mouse dan $\mathrm{PS} / 2$, biasanya digunakan pada pent 3 dan 4

d) Mouse USB (Universal Serial Bus), mouse dengan konektor USB.

e) Mouse nirkabel/nirkabel, mouse nirkabel. Mouse ini terhubung ke komputer melalui gelombang radio atau inframerah atau dengan sistem Bluetooth. Mouse tanpa kabel lebih mahal daripada mouse serial atau mouse Uniprsal Serial Bus.

f) Optical Mouse Mouse jenis ini menggunakan teknologi sinar laser atau lampu LED (Light Emitting Diode) untuk mendeteksi pergerakan mouse.

g) Dan memantulkannya sehingga mengenai sensor dan menjadi pemerintah untuk diteruskan ke CPU.

1) Panel sentuh

Unit info ini biasanya 8pat ditemukan di PC dan buku catatan, dengan menggunakan sedikit jari. Umumnya unit ini dapat digunakan daripada mouse. Selain touchpad, 1 la model unit info pembanding, khususnya pointing stick dan trackball.

2) Pena Ringan

Light Pen adalah penunjuk elektronik yang digunakan untuk mengatur dan mengkonfigurasi gambar dengan (layar). Light Pen memiliki sensor yang dapat menyampaikan pesan cahaya ke PC yang kemudian direkam, dimana layar bekerja dengan merekam 6 tanda elektronik setiap baris/detik.

3) Bantalan Grafis

Inovasi PC Aided Design (CAD) dapat membuat rencana untuk struktur, rumah, motor, dan pesawat menggunakan Graphics Pads. Ilustrasi Pad adalah input input untuk menggambar objek di layar. Desain Pads yang digunakan ada 2 macam. Pertama-tama, menggunakan jarum (penunjuk) yang terkait dengan bantalan atau dengan menggunakan bantalan tegangan rendah, yang memiliki permukaan film halus pada bantalan. Tegangan rendah yang dikomunikasikan kemudian diubah menjadi xy memfasilitasi. Yang kedua ad 3 hen mengunakan bantalan lembut sentuh tanpa menggunakan jarum. Cara kerjanya adalah dengan meletakkan kertas gambar di atas bantal, lalu kemudian menyusunnya dengan pensil.

4) Pemindai

Berfungsi untuk memasukkan informasi sederhana ke dalam informasi yang terkomputerisasi dengan memeriksa gambar dari pemindai ke dalam PC. Kapasitas untuk menggandakan/menggandakan gambar atau teks yang kemudian disimpan ke dalam memori PC sebagai gambar. Pemindai praktis seperti pemindai, tetapi yang penting adalah bahwa dalam pemindai kita dapat mengubah dokumen yang 3replikasi melalui layar sebelum mencetak hasilnya.

Saat ini sedang dibuat pemindai dengan inovasi DMR (Digital Mark Reader). Gunakan untuk menjawab lembar jawaban PC (LJK), biodata, dan struktur. Namun dengan inovasi DMR, lembar jawaban tidak perlu disusun menggunakan pensil 2B, tetapi dapat menggunakan pulpen, spidol dan alat tulis lainnya serta dapat menggunakan kertas biasa. 
5) Joy stick dan dayung permainan

Perangkat 3 biasanya digunakan dalam game PC. Bliss stick biasanya berbentuk tongkat, sedangkan dayung permainan biasanya berbentuk kotak atau kotak yang terbuat dari plastik yang dilengkapi dengan tombol yang akan mengatur pergerakan artikel di PC.

A. Gadget Proses (Processing Unit)

Unit penanganan atau $\mathrm{CPU}$ (Central Processing Unit) merupakan instrumen atau unit utama dalam sebuah framework PC. Tugas dasarnya adalah untuk mengontrol seluruh kerangka kerja PC selama penanganan informasi. $\mathrm{CPU}$ adalah tempat untuk menar8ani pedoman - arah program pada komputer mikro yang disebut chip, prosesor ini terdiri dari ribuan dan jutaan IC.

\section{Catu Daya}

Power Supply berperan sebagai penyedia daya dalam sebuah rangkaian PC. Kontribusi bagian ini adalah dengan mensubstitusi aliran listrik (AC) kemudian, pada saat itu, satu daya berubah dari aliran berputar menjadi aliran langsung (DC), aliran langsung ini benar-benar dimanfaatkan oleh bagian-bagian di PC. Catu 5aya dapat diputar di sana-sini melalui tombol On-Off yang terletak di bagian depan casing PC.

\section{Prosesor}

Prosesor adalah nama pendek untuk microchip dan sering disebut CPU (Central Processing Unit). Bagian ini sebagai sebuah chip (IC/Integrated Circuit) adalah sepotong silikon persegi kecil yang mengandung ribuan atau bahkan sejumlah besar semikonduktor dan bagian listrik lainnya. Prosesor adalah salah satu bagian utama dalam sebuah kerangka kerja PC, prosesor sering disebut sebagai otak besar dari PC karena merupakan pengolah informasi. Model: Pentium 3. Pentium 4, Celleron, AMD dan sebagainya

\section{Motherboard}

Motherboard sekarang dan lagi disebut papan kerangka, papan utama dan plannar. Bagian yang dipasang selamanya (tidak dapat dilepas) dan ruang atau lampiran untuk memasukkan bagian yang dapat dilepa 14 seperti kartu suara, kartu I/O, chip microchip, dan chip RAM. Ada beberapa motherboard yang telah dilengkapi dengan I/o nonremovable yang diketahui terpasang. hasil)

4. Hasil gadget (gadget

Gadget hasil adalah gadget yang digunakan untuk menyampaikan hasil proses. Model, misalnya, layar layar, printer, plotter, kartu acara, dan speaker. Gadget hasil atau gadget hasil adalah gadget yang terdiri dari perangkat yang menginterpretasikan perintah 
yang telah ditangani oleh PC ke dalam struktur yang dirasakan oleh orang-orang. Ada 2 jenis utama perangkat hasil, yaitu Softcopy, seperti layar dan suara, dan Hardcopy, seperti printer, plotter.

\section{A. Monitor}

Layar adalah hasil atau hasil gadget yang berfungsi untuk menampilkan efek samping dari sistem berhitung. Arah yang kita masuk ke PC akan ditampilkan di layar. Presentasi di layar diperkirakan oleh unit piksel, semakin tipggi piksel, semakin tinggi tujuan layar, semakin tajam dan jelas gambar yang ditampilkan.

Ada beberapa jenis layar PC, yaitu layar CRT dan layar LCD tertentu. Layar CRT (cathode beam tube) adalah layar yang memiliki silinder. Layar LCD (etalase batu mulia cair) adalah layar permata air yang banyak digunakan di PC/notebook PC. Namun, saat ini banyak layar PC yang menggunakan teknologi LCD.

Misalnya, sasaran $1 \frac{024}{2}$ x768 menyiratkan bahwa layar berisi 1.024 baris piksel dan 768 bagian piksel, pada akhirnya, jumlah piksel yang diatur di layar adalah $1.024 \mathrm{x}$ 768 buah. Semakin menonjol tujuannya, semakin baik kualitas gambar atau tampilan layarnya.

\section{B. Proyektor}

Proyektor adalah alat yang mampu memproyeksikan atau mengirim informasi atau slide yang diperoleh dari PC, DVD player, TV atau media cetak lainnya. Tak kalah signifikan dalam pemanfaatan LCD proyektor. Layar proyektor adalah layar yang digunakan sebagai tempat untuk mengeluarkan LCD proyektor. Ada salahnya memanfaatkan layar yang akan diganti dengan sekat warna putih. Bagaimanapun, ada keuntungan menggunakan proyektor layar, khususnya sumber cahaya LCD dapat dihasilkan dari belakang layar. Sehingga dalam perkenalan atau acara-acara yang menggunakan proyektor dapat terlihat lebih rapi.

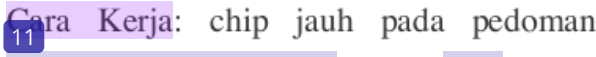
pembiasan cahaya yang dibuat oleh papan LCD. Papan ini dibuat secara independen tergantung pada nada esensial, merah, hijau dan biru (R-G-B). Jadi ada tiga papan LCD di proyektor. Bayangan gambar yang tidak ditransmisikan oleh proyektor adalah efek dari pembiasan dari papan LCD yang telah digabungkan dengan kristal yang luar biasa. Gambar gabungan ${ }_{25}$ sebut kemudian hilang dari perspektif dan dijatuhkan di layar sehingga cenderung dianggap sebagai gambar total.

\section{Pencetak}

Printer adalah peralatan yang digunakan untuk mencetak di atas kertas, dalam perkembangannya. Pencetakan pinter dibagi menjadi: Oleh karena itu, printer jenis ini sering disebut pound, karena pencetakan diselesaikan dengan menempelkan setumpuk pena (jarum) pada pita tinta. Daerah pin sangat dekat satu sama lain sehingga presentasi huruf tidak diganggu $_{5}$ Jumlah pin berubah dari 9 menjadi 24 pin, semakin banyak jumlah 
pin, semakin halus komposisi yang dihasilkan. Kelebihan printer ini terletak pada kemampuannya untuk mencetak pada kertas fotokopi yang tidak dapat dilakukan oleh printer lain, yang meliputi printer jenis ini, antara lain:

Dot Matrik, (Printer yang menggunakan kepola cetak berupa sekumpulan pin). Printer dot matrik adalah jenis yang resolusi cetaknya masih sangat rendah hal ini disebabkan karena print head printer jenis ini terdiri dari jarumjarum yang tersusun (sekitar 9-24 pin), nantinya jarum-jarum ini akan memunculkan pita (printer ribbon) sehingga membentuk sebuah karakter pada kertas. Printer jenis dot matrik mempunyai kekurangan dalam hal kualitas cetakan yang tidak sebagus printer inkjet dan laserjet, printer jenis ini hanya cocok untuk mencetak dokumen berupa tulisan saja dan umumnya printer dot matrik hanya mempunyai satu warna, yaitu warna hitam. Sering ditemukan di wartel, supermarket, apotik.

1. Daisy Wheel, (Printer yang menggunakan roda berisi karakter10rakter)

Printer jenis ini menggunakan kumpulan huruf yang tersusun dalam sebuah piringan. Oleh pemakai, piringan ini bisa digantiganti sesuai dengan jenis huruf yan diingkan. Cara bekerjanya relatif sangat lambat serta tidak lebih cepat dari mesin ketik listrik. Walaupun begitu, kualitas huruf yang ditampilkan sangatlah bagus. Pada saat mencetak, mekanisme dari printer akan memutar piringan sehingga posisi huruf yang dibutuhkan bisa tepat pada tempat yang dibutuhkan. Pada posisi seperti itu, hammer (palu/pemukul) akan menekan huruf yang bersangkutan sehingga menyentuh pita (karbon) dan kemudian diteruskan di atas kertas yang berada dibalik karbon/pita. Terjadilah pencetakan huruf demi piringan sehingga posisi huruf yang dibutuhkan bisa tepat pada tempat yang dibutuhkan. Pada posisi seperti itu, hammer (palu/pemukul) akan menekan huruf yang bersangkutan sehingga menyentuh pita (karbon) dan kemudian diteruskan diatas kertas yang berada di balik karbon/pita. Terjadilah pencetakkan huruf demi huruf. Dikarenakan cara mencetak printer jenis ini berdasar huruf demi huruf, maka printer ini juga dikenal sebagai character-printer. Kecepatan cetaknya relatif lambat, yaitu berkisar 40 hing 100 character per-second.

2. Line Printer, (Printer yang mencetak satu baris perwaktu)

Printer baris mencetak satu baris teks sebelum melanjutkan ke baris lain. Sebagian besar printer lini awal printer dampak. Line printer 
sebagian besar terkait dengan peralatan unit record dan hari-hari awal komputasi digital, tetapi teknologi ini masih digunakan.

Thermal, Printer thermal merupakan pilihan terbaik bagi keluaran yang cetakan berwarna dengan kualitas tinggi. Cetakan berwarna printer thermal memerlukan kertas berlapis lilin atau parafin, dan panas akan membakar titik-titik pada kertas khusus tersebut sehingga hasil cetakannya pun bagus. Untuk cetakan hitam putih, printer thermal tidak memerlukan kertas khusus bisa dengan kertas biasa.

1. Ink-Jet, Printer Ink-Jet adalah printer yang memberikan cetakan dengan cara menyemprot titik-titik tinta yang bermuatan listrik ke kertas cetakan, printer ini bisa digunakan untuk cetak berwarna atau hitam putih, mencetak pada kertas biasa atau pad plastic untuk bahan presentasi.

2. Laser, Printer Laser yang memberikan hasil yang terbagus, printer ini dirancang untuk komputer Mainframe karena memiliki kecepatan sekitar 229 hal per menit, sedangkan untuk komputer PC dengan kecepatan 4 sampai 25 hal permenit.

3. Multifungsi, Printer multifungsi merupakan jenis printer yang memiliki berbagai fungsi, misalnya digunakan untuk : fotocopy, scanner, bahkan ada bisa untuk fax.
Speaker adalah transduser yang mengubah sinyal elektrik ke frekuensi audio (Suara) dengan cara menggetarkan komponen nya yang berbentuk selaput.

\section{CSistem Perangkat Keras Masukan (Input Device System)}

Sebagai peralatan yang di fungsi kan untuk memasukkan data ke Dalam komputer.Jenis inp ut device yang dimiliki oleh komputer cukup

Banyak diantaranya:

- Keyboard

- Mouse

- Touchscreen

- Scanner Barcode mengalami perkembangan yang cukup signifikan.

\section{Saran}

1. Setelah memeriksa peralatan dan program komputer di komputer, pencipta dapat memberikan proposal sesuai kebutuhan. Sangat penting untuk mengembangkan kemajuan dan penggunaan peralatan dan program komputer di komputer.

2. Setiap mahasiswa untuk mendorong metode pembelajaran mata kuliah harus mampu memfungsikan program dan peralatan pada komputer.

3. Dalam waktu yang akan datang peningkatan peralatan dan program akan meningkat pesat.

\section{Processing Unit (CPU)}

\section{B. Speaker}


Sebagai tempat penanganan informasi atau bisa juga dikatakan sebagai otak dari semua latihan penanganan seperti memeriksa, menyortir, mencari, mengarang, meneliti dan sebagainya. 5 Di CPU ada beberapa

Komponen perangkat seperti:
a) Processor
b) RAM(Random Access Memory)
c) $\operatorname{ROM}($ Read Only Memory)
d) Papan Induk/ MotherBoard
e) Cache Memory

Berbagai jenis chip memori Yield Gquipment (Yield Gadget Framework) Sebagai perangkat yang diberdayakan untuk mengeluarkan masalah persiapan CPU,

seperti tuli 6 n(huruf,angka,karakterkusus,simbolla in),grafik,gambar/ image,suara dan bentuk khusus yang dapat dibaca oleh mesin. Jenis output device yang dimiliki oleh komputer cukup banyak diantaranya:

- Monitor/Screen/Display oSpeaker

- Printer oPlotter oMesinFax odll.

2. Sistem perangkat keras tambahan (Peripheral/ Accessories

DeviceSystem)

Difungsikan sebagai penambahan kemampuan dari sistem komputer

Seperti dapat berbagi file dan data antara komputer.Perangkat peripheral

seperti:

Modem

$>{ }_{2}^{\top}$ etworkCard/Ethernet Gambar16.LANcard

TVCard KartuGrafis/VGACard

Gambar 17.KartuGrafis/VGACard

KartuSuara/SoundCard dll.

Sistem perangkat keras cadangan (secondarystorage/backingstorage/ externalmemory) diperuntukkan sebagai tempat penyimpanan data, file dan program yang berada di luar sistem utama.Contoh perangkat keras cadangan ini adalah sebagai berikut:

- Disket,HardDisk 2 FlashDisk,MagneticTape

- KepingCD/DVD(CD/DVDRoom)

\section{Sistem Perangkat Keras Masukan (Input Device System)}

Sebagai peralatan yang difungsikan untuk memasukkan data kedalam komputer. Jenis input device yang dimiliki oleh komputer cukup banyak diantaranya :

\section{Keyboard \\ Mouse \\ $>$ Touchscreen \\ $>$ Sensor sidik jari/Finger \\ Print \\ Camera \\ Microphone \\ D11}

$>$ 6canner

\section{Studi Literatur Perangkat Keras}

Perangkat keras komputer adalah semua bagian fisik komputer, dan dibedakan dengan data yang berada didalamnya atau yang beroperasi didalamnya, dan dibedakan dengan perangkat lunak (software) yang menyediakan intruksi untuk perangkat keras dalam 
menyelesaikan tugasnya.

Adapun penelitia 2 menurut dari Ali Zaki disebut juga bagian fisik dari komputer, termasuk sirkuit digital didalam perangkat komputer.

Hardware

Adapun Fungsi Komponen

1. Unit Masukkan (Input device)

2. Proses Device (Unit Pemprosesan)

3. Output Device (Perangkat Pengeluaran)

4. Sistem Perangkat Keras Masukkan (Input Device System)

5. Processing Unit (CPU)

\section{PENUTUP}

\section{Kesimpulan}

Dari penjelasan yang dilakukan diatasmakadapatditarikke simpulan 5 bagai berikut:

Perangkat keras dan perangkat lunak

pada komputer tidak dapat dipisahkan.Karena masing- masing 5 ling membutuhkan. Perkembangan perangkat keras dan perangkat lunak pada komputer sangatlah tinggi.

\section{REFERENSI}

http://iqimedia.blogspot.com/2012/11 Imengenal-

perangkatkomputer $10 . \mathrm{html}$

http://tentangkomputerkita.blogspot.c om/2010/04/pengertian-

perangkatlunak-software.html

http://teknohikmah.blogspot.com/201 1/01/kemajuan-hardware-dan-os-daripc-dan.html

http://id.wikipedia.org/wiki/Wikipedi a_bahasa_Indonesia

Yahfizham.2019.DasardasarKompute r.Medan:PerdanaPublishing.

Buku Pengenalan Komputer dan Teknologi Informasi

Penulis: Samsudin, dkk

Editor: M. Irwan Nasution dan Ismail Husein

http://iqimedia.blogspot.com/

2012/11/mengenalperangkatkomputer_10.html

Ali Zaki, 2010.Panduan Hardware Komputer. .Semarang:CV.AndiOffset

Bobi Kurniawan, 2013.Perangkat keras komputer:Panduan Mengenal Hardware Komputer.PT.Elex Media Komoutindo, 164 ha 
Putri, Nency, dkk. Aplikasi Berbasis Multimedia untuk Pembelajaran Perangkat Keras Komputer, V1.i2(7081), Jurnal Edik Informatika.

Yahfizham, 2019.Dasar-Dasar-

Komputer. Medan:Perdana

Publishing 
jurnal_febry_1_1.docx

ORIGINALITY REPORT

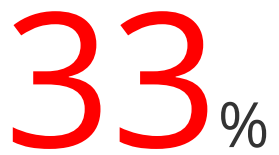

SIMILARITY INDEX
$33 \%$

INTERNET SOURCES
$1 \%$

PUBLICATIONS
$6 \%$

STUDENT PAPERS

PRIMARY SOURCES

1 teknikinformatika2013.files.wordpress.com

Internet Source

2 mfr.osf.io

$6 \%$

Internet Source 
11 wWw.kaskus.co.id

12 xpermanax.wordpress.com

13 Submitted to Universitas Muria Kudus

14 arisfirmssug.blogspot.com

15 officialnarastore.wordpress.com

16 wijayalabs.com

17 pakdosen.pengajar.co.id

19 repository.trisakti.ac.id 
23 adamarfansyah.wordpress.com

24 kaoasada.blogspot.com 